\title{
Coeliac disease with autoimmune haemolytic anaemia
}

\author{
D. G. MILLER \\ M.B., Ch.B., M.R.C.P. (U.K.) \\ Gastrointestinal Unit, Hull Royal Infirmary, Hull HU3 2JZ
}

\begin{abstract}
Summary
Two patients are described who have developed autoimmune haemolytic anaemia in association with their coeliac disease. Autoimmune haemolytic anaemia may represent an extension of immunological disorders linked with coeliac disease, centred on the histocompatibility antigen B8.
\end{abstract}

KEY WORDS: coeliac disease, autoimmune haemolytic anaemia.

\section{Introduction}

Coeliac disease has been found in association with chronic liver disease, connective tissue disorders, diabetes mellitus, thyroid diseases, psoriasis, ulcerative colitis and Addison's disease, all of which are considered to have an immunological basis (Cooper, Holmes and Cooke, 1978).

Two patients are described, who have developed autoimmune haemolytic anaemia in association with their coeliac disease: one also had psoriasis, and the other hypothyroidism and chronic aggressive hepatitis.

\section{Case 1}

A 17-year-old man with a 10-year history of psoriasis presented with 2-month lethargy and weight loss without diarrhoea and was found to have a macrocytic anaemia. Investigations revealed haemoglobin $10.6 \mathrm{~g} / \mathrm{dl}$, mean cell volume (MCV) $109 \mathrm{fl}$, erythrocyte sedimentation rate (ESR) $65 \mathrm{~mm} / \mathrm{hr}$, white cell count (WBC) $5 \cdot 1 \times 10^{9} /$ litre, red cell folate $<50 \mu \mathrm{g} /$ litre, serum vitamin $B_{12} 330 \mathrm{ng} /$ litre, ferritin $170 \mu \mathrm{g} /$ litre. Bone marrow florid megaloblastic changes, calcium $2.17 \mathrm{mmol} /$ litre, $(8.68 \mathrm{mg} / 100 \mathrm{ml})$, albumin $42 \mathrm{~g} /$ litre, xylose excretion $15 \%$ of $25 \mathrm{~g}$ dose over $5 \mathrm{hr}$. Jejunal biopsy: subtotal villous atrophy with crypt hyperplasia and inflammatory cell infiltrate.

A diagnosis of coeliac disease was made and following a gluten-free diet and oral folic acid, he gained $13.4 \mathrm{~kg}$ in weight over 4 months and his haemoglobin rose to $15 \cdot 5 \mathrm{~g} / \mathrm{dl}$. The MCV fell to $81 \mathrm{fl}$. He would not agree to a repeat jejunal biopsy.

One year later he became jaundiced and investigations revealed: haemoglobin $15 \cdot 2 \mathrm{~g} / \mathrm{dl}, \mathrm{MCV} 105 \mathrm{fl}$, WBC $12.6 \times 10^{9} /$ litre, platelets $350 \times 10^{9} /$ litre reticulocytes $20 \%$ with spherocytes, bilirubin $95 \mu \mathrm{mol} /$ litre, $5.5 \mathrm{mg} / 100 \mathrm{~mol})$, direct Coombs' test positive with IgG antibody, antinuclear and smooth muscle antibodies negative, serum protein electrophoresis, chest $\mathrm{X}$-ray small bowel enema and lymphangiogram all normal. HLA status A B8 W6.

Steroid therapy produced only a partial remission in his haemolytic anaemia. Later a splenectomy was performed following which he has remained well and his haemoglobin rose from the pre-operative level of $12.8 \mathrm{~g} / \mathrm{dl}$ to normal. The spleen was twice the normal size.

\section{Case 2}

A 43-year-old man presented in 1979 with symptoms of myxoedema. Thyroglobulin and microsomal antibodies in a titre of 1:1,280 and 1:6,400 respectively were found. A diagnosis of Hashimoto's thyroiditis was made and replacement thyroxine 0.2 mg daily commenced. The blood count at this time was normal.

In 1980 he developed jaundice and dark urine. Investigations revealed: haemoglobin $6.4 \mathrm{~g} / \mathrm{dl}, \mathrm{MCV}$ $104 \mathrm{fl}$, WBC $2.7 \times 10^{9} /$ litre, platelets $68 \times 10^{9} /$ litre, reticulocytes $14.4 \%$, ESR $42 \mathrm{~mm} / \mathrm{hr}$, bilirubin 61 $\mu \mathrm{mol} /$ litre, $(3.57 \mathrm{mg} / 100 \mathrm{ml})$, direct Coombs' test positive with non-specific antibody, Ham's acid test negative, anti-nuclear, smooth muscle and anti-mitochondrial antibodies negative, bone marrow: erythroid hyperplasia with slightly reduced granulopoiesis.

A partial remission of his haemolytic anaemia followed steroid therapy, with haemoglobin improving to $12.2 \mathrm{~g} / \mathrm{dl}$ although thrombocytopenia persisted.

In May 1982 whilst on prednisolone $7.5 \mathrm{mg}$ daily he complained of 6 months diarrhoea with stool frequency 6 times daily and 6 weeks ankle swelling 
and $4 \mathrm{~kg}$ weight loss. Investigations revealed: albumin $27 \mathrm{~g} /$ litre, stool cultures no pathogens, small bowel enema normal. Jejunal biopsy: severe partial villous atrophy with crypt hyperplasia and plasma cell infiltrate.

A diagnosis of coeliac disease was made and following a gluten-free diet he symptomatically improved, gained $2 \mathrm{~kg}$ in weight over 1 month and his bowel frequency settled to twice daily.

In July 1982 he presented with a 1-week history of jaundice, pale stools, dark urine and lethargy. He denied any rashes, arthralgia, recent foreign travel or injections. Clinical examination confirmed jaundice with hepatosplenomegaly.

Investigations: bilirubin $575 \mu \mathrm{mol} /$ litre $(33.63$ $\mathrm{mg} / 100 \mathrm{ml}$ ); alanine aminotransferase $2,140 \mathrm{iu} /$ litre; and alkaline phosphatase $195 \mathrm{iu} /$ litre, but no evidence of further haemolysis or hepatitis A, B, cytomegalovirus, leptospirosis or Coxiella burnetti infection. He unfortunately later died from hepatorenal failure. At post mortem, microscopy of the liver showing severe chronic aggressive hepatitis was confirmed; HLA status was not determined.

\section{Discussion}

Coeliac disease is increasingly believed to have an immunological basis. One of the supporting argu- ments is the number of other indisputable immunolo gical conditions which may complicate coeliac dise ease (Falchuk, 1979).

The histocompatibility antigen B8 has been foun $\overrightarrow{\overline{\bar{\phi}}}$ in association not only with coeliac disease, but witt myasthenia gravis, thyroid disease, insulin-depeno

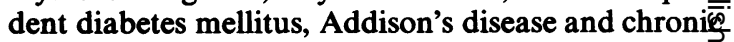
active hepatitis (Asquith, 1979). Autoimmune hae molytic anaemia may be a further manifestation in the spectrum of autoimmune disease associated with this genotype.

\section{Acknowledgments}

I thank Drs J. R. Bennett and D. R. Sutton for their help and permission to report on patients under their care, and Mrs P. Milnef; for her secretarial assistance.

\section{References}

ASQUITH, P. (1979) Immunology of the Gastrointestinal Tract, p. 89 ? Churchill Livingstone, Edinburgh.

COOPER, B.T., Holmes, G.K.T. \& CoOKE, W.T. (1978) Coeliac. disease and immunological disorders. British Medical Journal, oه 537.

FALCHUK, Z.M. (1979) Update on gluten sensitive enteropath American Journal of Medicine, 67, 1085.

(Accepted 8 September 1983)

.

